Article

\title{
Riparian Forest Restoration: Conflicting Goals, Trade-Offs, and Measures of Success
}

\author{
Heather L. Bateman ${ }^{1, *}$, David M. Merritt ${ }^{2}$ and J. Bradley Johnson ${ }^{3}$
}

1 Arizona State University, Polytechnic Campus, 6073 S Backus Mall, Mesa, AZ 85212, USA

2 USFS Watershed, Fish, and Wildlife \& CSU Natural Resource Ecology Laboratory NRRC, Fort Collins, CO 80523, USA; E-Mail: dmmerritt@fs.fed.us

3 Colorado State University, Department of Biology, Fort Collins, CO 80523, USA;

E-Mail: bjohnson@lamar.colostate.edu

* Author to whom correspondence should be addressed; E-Mail: heather.bateman@gmail.com; Tel.: +1-480-727-1131; Fax: +1-480-727-1236.

Received: 29 June 2012; in revised form: 23 July 2012 / Accepted: 1 September 2012 /

Published: 19 September 2012

\begin{abstract}
Restoration projects can have varying goals, depending on the specific focus, rationale, and aims for restoration. When restoration projects use project-specific goals to define activities and gauge success without considering broader ecological context, determination of project implications and success can be confounding. We used case studies from the Middle Rio Grande (MRG), southwest USA, to demonstrate how restoration outcomes can rank inconsistently when narrowly-based goals are used. Resource managers have chosen MRG for restoration due to impacts to the natural flood regime, reduced native tree recruitment, and establishment of non-native plants. We show restoration "success" ranks differently based upon three goals: increasing biodiversity, increasing specific ecosystem functions, or restoring native communities. We monitored 12 restored and control sites for seven years. Treatments ranked higher in reducing exotic woody populations, and increasing proportions of native plants and groundwater salvage, but generally worse at removing fuels, and increasing species and habitat structural diversity. Managers cannot rely on the term "restoration" to sufficiently describe a project's aim. Specific desired outcomes must be defined and monitored. Long-term planning should include flexibility to incorporate provisions for adaptive management to refine treatments to avoid unintended ecological consequences.
\end{abstract}


Keywords: riparian; restoration; ecological services; ecological standards; monitoring; invasive species

\section{Introduction}

Ecological restoration projects focus on the recovery of an ecosystem that has been degraded or damaged [1]. According to Van Diggelen et al. [2] and Ruiz-Jaen and Aide [3] restoration projects can take on three levels of intensity and associated project goals. One level, considered reclamation, may for example have the restoration goal of increasing the biodiversity of a highly degraded system [4,5]. The next two levels may involve the reintroduction of an ecosystem function or the re-establishment of species or communities to an ecosystem [6]. By evaluating the trajectory of recovered ecosystems, restoration practitioners can assess how restoration projects accomplish desired outcomes or goals [3]. Although some guidelines are suggested as measures to gauge restoration successes [1,7], there is no quantitative evidence showing that by accomplishing each of the specific goals (i.e., diversity, community structure or ecosystem function) a project will lead to the same assessment of restoration success or failure. Gauging restoration success on an overly narrow or poorly defined set of criteria is problematic. For example, when criteria are too narrow, restoration activities may have broader effects than the focused goal causing secondary effects which may or may not represent a desired management outcome. When criteria are poorly defined, evaluation of success is confounded because different measures of restoration success may lead to conflicting conclusions.

Restoration projects should not only be assessed by how different activities contribute to reaching stated management goals, but also the consequences of those activities on other ecosystem components [8]. Defining project goals without a broader set of ecological objectives may obscure the relative merits or drawbacks of specific restoration treatments, making treatment choice unclear or confusing. Here we present analyses to rank several activities commonly used by restoration practitioners based on how they accomplish several common restoration project goals (sensu $[9,10])$.

Using the Middle Rio Grande (MRG) Riparian Restoration project in New Mexico, USA, we can experimentally test how varying project goals, without clearly defined ecological objectives, affect the evaluation of restoration methodologies. Resource managers have chosen the MRG for restoration because anthropogenic activities have altered the natural flooding regime, cottonwood (Populus deltoides subsp. wislizenii) recruitment, and plant species composition [11]. In the 20th century, engineers dammed and channelized the MRG to reduce the frequency and severity of flooding, and to facilitate agriculture and water management [12]. As a result, many natural processes in the riparian forest ecosystem have been disrupted or altered. For example, spring floods historically scoured channel margins and deposited new sediment on which cottonwood seedlings germinated $[13,14]$. The absence of spring flood events has allowed invading plants such as saltcedar (Tamarix ramosissima) and Russian olive (Elaeagnus angustifolia) to establish on sites formerly available to native cottonwood trees [13]. The quantities of woody debris in many areas of the riparian forest have increased substantially due the lack of scouring floods and rates of decomposition on the now dry floodplain $[11,15]$. The non-native plant introductions that generally follow hydrological alteration can 
also lead to further changes in water available to native vegetation and changes in the form and function of riparian plant communities.

Amphibians and reptiles (herpetofauna) play important roles within ecosystems. Similar to many birds and mammals they are major consumers of terrestrial arthropods [16]. However, amphibians and reptiles are more efficient at converting food into biomass and are a higher quality food source for predators [17]. Recent declines in some herpetofaunal populations have stimulated a greater overall interest in the monitoring of these populations [18,19]; therefore, it is reasonable that resource managers would monitor these wildlife species during and following restoration projects.

In order to assess how varying project goals can lead to confusion of the evaluation of restoration success, we rank three restoration techniques by how they accomplish specific project goals. We use two case studies along the MRG to evaluate hypothetical, yet probable, project goals. We evaluate how restoration treatments rank within each case study to accomplish three levels of project goals including how treatments affect: (1) native biodiversity (either by removing exotic species or increasing total species richness), (2) ecosystem function (such as fire risk or groundwater availability and use) and (3) restoring communities (such as historic wildlife communities or habitat structural diversity). We define habitat in terms of vegetation structure instead of the biological, physical, and chemical elements of a system (sensu [20]). We tested the hypothesis that treatments will rank differently based upon three levels of treatment intensity. We predicted that in the absence of ecological objectives, divergent project goals will lead to confusion in evaluating which restoration activity is the best overall treatment which a resource manager may select to implement. For example, the most appropriate treatment to minimize water use by non-native vegetation may not necessarily be the best treatment for, and may indeed be in direct conflict with, supporting a diverse wildlife community.

\section{Research Methodology}

\subsection{Restoration Treatments}

Restoration treatments were conducted at 12 sites (approximately 20 ha each) for seven years in three geographically distinct segments (i.e. North, Middle, South) along the MRG. Each region had four sites; three were experimental and one was a control. Each experimental site was randomly assigned to one of three treatments to remove non-native plants (hereafter, treatment; Figure 1). Treatment 1 consisted of removing non-native plants and dead, woody-debris. Crews used chainsaws to remove non-native plants and herbicide (i.e., Garlon) was applied to stumps. Treatment 2 consisted of procedures in Treatment 1 followed by a light, prescribed fire. Treatment 3 consisted of procedures in Treatment 1 followed by revegetation with native shrubs. Control sites experienced no treatment.

Not all experimental sites were treated simultaneously owing to the magnitude of the undertaking. As a result, the duration of pre-treatment conditions varied from three to five years, and posttreatment conditions varied from two to four years. Non-native plant removal began in 2003 and was completed in 2005.

Two case studies were undertaken between 2003 and 2006. These studies evaluated all, or a subset of MRG experimental sites, to determine the effect of treatments on vital attributes of the forest system which might be used to gauge restoration success. 
Figure 1. (a) Riparian woodland along the Middle Rio Grande, New Mexico, USA; (b) Treated site to remove non-native plants with a native cottonwood (Populus deltoides subsp. wislizenii) overstory.
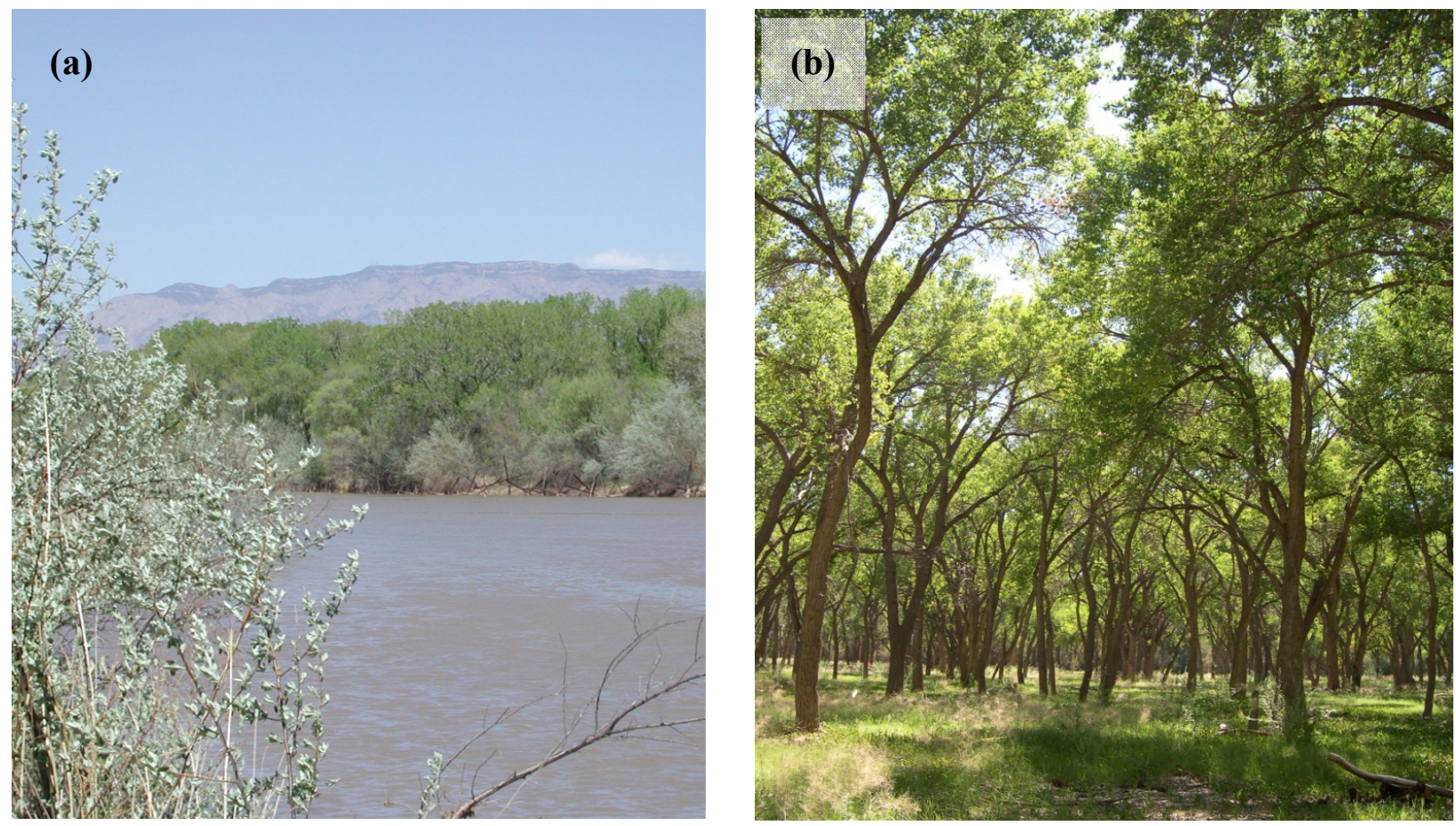

\subsection{Case Study I-Field Sampling}

We monitored herpetofaunal species from June to September from 2000 to 2006 and measured vegetation variables before and after treatments. Descriptions of herpetofauna sampling techniques are described in [21]. We compiled a list of historic species present in the MRG from 1938 to 1995 from monitoring projects along the MRG [22-24] and records of specimens from the Museum of Southwestern Biology. Museum specimens were georeferenced using a $400 \mathrm{~m}$ buffer around the MRG in Bernalillo, Valencia, and Socorro Counties, New Mexico. Species richness of amphibians and reptiles per site was compared to historic composition. A species was considered 'gained' when it was absent before treatment but present after treatment and found in historical records. A species was considered 'lost' if it was present before treatment and found in historical records but absent after treatment.

Numbers of non-native saltcedar and Russian olive trees and amount of fuels were measured along $50 \mathrm{~m}$ transects and in $4 \mathrm{~m}$ radius plots in conjunction with herpetofauna sampling (also described in [21]). Ground fuel load (metric tons per ha) was estimated with Fuels Management Analyst software [25].

\subsection{Case Study II-Field Sampling}

Habitat structure, defined in terms of vegetation structure, was quantified in treated (Treatment 1 and 3) and control sites in 2006. During Case Study II, too few sites were available in Treatment 2 for analyses, because of drought and restrictions on controlled burns. Percent understory cover and total 
number of native and non-native plant species were measured in $2 \times 2 \mathrm{~m}$ plots. Woody species cover was measured using the line intercept method along transects. Percent cover was estimated using cover classes. Overall, we evaluated 1820 plots and $3628 \mathrm{~m}$ of transect. Foliage height diversity was calculated using percent cover of woody species in three height classes $(1-5 \mathrm{~m}, 5-15 \mathrm{~m}$, and $>15 \mathrm{~m})$ to calculate Shannon H (measure of diversity). Species richness was estimated using species accumulations curves and Michaelis Menten (MM) richness estimators using Estimate-S software [26,27]. Description of the methods and responses of vegetation to restoration treatments and controls are described in [28].

Groundwater wells were manually bored and a steel well-casing was pounded in so that about 0.8 meters protruded above the soil surface. Each well casing had an interior diameter of $5.1 \mathrm{~cm}$ and an external diameter of $6 \mathrm{~cm}$. Each well extended approximately $4 \mathrm{~m}$ below the soil surface and was screened across the bottom $1.5 \mathrm{~m}$ of the casing with $0.5 \mathrm{~mm}$ slotted stainless steel screen. Each well was equipped with a gaged (vented-cable) data logger (miniTROLL, In-Situ, Inc.). Depth to groundwater (DTW) was sampled every 15 or 30 minutes. Each well was originally equipped with an Electronic Engineering Innovations Model 5.0 vented logger. On 27 April 2005, loggers were replaced with Solinst 2001 M10 Mini LT Levelloggers. Correction for barometric pressure was achieved via an on-site Solinst 3001 M1.5 Mini LT Barologger. Detailed groundwater measurement methodology is presented in Gunning [29]. Changes in evapotransirational use was evaluated through quantifying differences in diurnal groundwater fluctuations between control and treated sites over the peak of the growing season (July and August) during the period of study. Ranks of ground water salvage were determined averaging the percent water savings across all years and both seasons per site.

\subsection{Analyses}

Treatments and Controls were ranked within regions based on how well each treatment accomplished a specific project goal. The best rank was given a value of 1 . The overall experimental design employed a random block configuration; therefore, treatments were ranked based on the means of subsamples, giving one average and standard deviation across the three regions. Treatments and Controls were ranked first within each block. Then ranks were averaged for a particular treatment across all blocks. Therefore, the mean rank of a particular treatment represents the average of all scores across the three regions.

We tested for similarity in ranking among treatments using a non-parametric multi-response permutation procedure (MRPP) and Controls were included in analyses. Multiple comparisons were based on Peritz Closure [30].

In order to evaluate the restoration treatments and give recommendations to land managers, it was important to detect differences due to treatments where they existed. Therefore, to decrease the probability of Type II error [31], we set our alpha level to 0.10 . 


\section{Results}

\subsection{Treatment Costs}

Treatments costs ranged from $\$ 7,550$ to $\$ 9,750$ per ha with Treatment 1 the lowest cost and Treatment 3 the highest cost (Table 1; [32,33]).

Table 1. Costs (per ha) of removing non-native plants and woody debris from three restoration treatments along the Middle Rio Grande, New Mexico. (Adapted from [32,33]).

\begin{tabular}{lccc}
\hline Description & $\begin{array}{c}\text { Treatment 1 } \\
\text { (thinned) }\end{array}$ & $\begin{array}{c}\text { Treatment 2 } \\
\text { (burned) }\end{array}$ & $\begin{array}{c}\text { Treatment 3 } \\
\text { (re-veg) }\end{array}$ \\
\hline Hand crews using chainsaws & $\$ 5,000-\$ 7,400$ & $\$ 5,000-\$ 7,400$ & $\$ 5,000-\$ 7,400$ \\
Herbicide $^{1}$ & $\$ 50-\$ 150$ & $\$ 50-\$ 150$ & $\$ 50-\$ 150$ \\
Prescribed burning-fire engine $^{2}$ & $\$ 400$ & $\$ 2,200$ \\
Planting native vegetation $^{2}$ & & & $\$ 9,750$ \\
Total (maximum) & $\$ 7,550$ & $\$ 7,950$ & \\
${ }^{1 .}$ Cut stumps treated with application of Garlon herbicide; ${ }^{2}$ Pole planting with 247 per ha \\
(100 plants per acre).
\end{tabular}

\subsection{Case Study I-Treatment Rankings}

Case Study I considered how treatments ranked with regard to their ability of reduce exotic woody cover, reduce fire risk through reduction of fuel load (metric tons/ha) and restore historic wildlife communities as illustrated by increases in amphibian and reptiles species richness. Treatments had different average ranking for each of the three restoration project goals (Table 2). Treatments contained significant variability among treatment type $(\mathrm{N}=12, p=0.02)$. Pairwise multiple comparisons showed that Treatment 1 differed from controls (Number of permutations $=35, p=0.03$ ) and that Treatment 1 marginally differed from Treatment 2 (Number of permutations $=15, p=0.13$ ).

Overall, not surprisingly, Treatment 1,2, and 3 ranked higher in removing exotic trees compared to controls (Table 2). However, both treatments and controls had a net gain of herpetofaunal species after restoration (Supplementary Material) and Treatment 1 and the Control were similar in rank (Table 2). Treatment 2 and the Control tied for best method to remove ground fuels; however, average fuel loadings were less in Treatment 2 compared to controls (Table 2). 
Table 2. In Case Study I, three restoration treatments were ranked by how they accomplished three levels of project goals from 12 sites along the Middle Rio Grande, New Mexico. Mean rank represents the average rank for that particular treatment compared to all other treatments and control with each region. Lowest ranks indicate the best treatment for accomplishing that goal.

\begin{tabular}{lcccc}
\hline Variable Treatment & N & $\begin{array}{c}\text { Mean } \\
\text { Rank }\end{array}$ & $\begin{array}{c}\text { Pre-treatment } \\
\text { Mean (SD) }\end{array}$ & $\begin{array}{c}\text { Post-treatment } \\
\text { Mean (SD) }\end{array}$ \\
\hline Number of Saltcedar, Russian olive & & & & \\
\hline Treatment 1 (thinned) & $12^{*}$ & 2.1 & $2.75(4.5)$ & 0 \\
Treatment 2 (burned) & $6^{*}$ & 2.3 & $0.33(0.5)$ & 0 \\
Treatment 3 (re-veg) & $9^{*}$ & 2.2 & $5.22(3.7)$ & 0 \\
Control & $9^{*}$ & 3.5 & $1.78(1.9)$ & $1.11(1.4)$ \\
\hline Fuel load (metric tons/ha) & & & & \\
\hline Treatment 1 (thinned) & $62 / 58^{*}$ & 3.8 & $28.87(24.56)$ & $90.43(125.73)$ \\
Treatment 2 (burned) & $32^{*}$ & 1.5 & $22.67(18.70)$ & $13.15(13.81)$ \\
Treatment 3 (re-veg) & $42 / 40^{*}$ & 2.5 & $32.27(44.04)$ & $42.45(46.42)$ \\
Control & $48 / 46^{*}$ & 1.5 & $23.45(23.52)$ & $18.10(21.82)$ \\
\hline Species gained (herpetofauna) & & & & \\
\hline Treatment 1 (thinned) & 4 & 2.1 & - & $3.0(1.8)$ \\
Treatment 2 (burned) & 2 & 3.5 & - & $1.5(3.5)$ \\
Treatment 3 (re-veg) & 3 & 2.8 & - & $3.0(2.0)$ \\
Control & 3 & 2.0 & - & $3.0(3.6)$ \\
\hline
\end{tabular}

${ }^{*}$ Number of exotic trees counted once before treatments and once after treatment. Tree counts are averaged from 3 plots per site (at herp arrays only); * Fuels measured once before treatments and once after treatment. Fuels are averaged from 16 plots per site (at bird stations and herp arrays). Number of plots differs because not all plots previously used were located a second time for post-treatment measurements.

\subsection{Case Study II-Treatment Rankings}

The restoration goals evaluated in Case Study II were increasing plant species richness and the proportion of native species, increasing groundwater salvage, and restoring habitat structural diversity. Treatments and controls had marginally significant variability in ranks based on how well they provided habitat structure ( $\mathrm{N}=9, p=0.06$; Table 3). Pairwise multiple comparisons showed that the control sites and Treatment 3 (re-vegetation) had the most different ranking (Number of permutations $=20$, $p=0.10)$.

Overall, controls ranked best in total plant richness, but worst in proportion of native plants compared to treatments (Table 3). Both treatments resulted in more groundwater salvage compared with controls, with Treatment 3 ranked the highest. Controls were ranked the highest in terms of habitat structural complexity compared to treatments (Table 3). 
Table 3. In Case Study II, two restoration treatments were ranked by how they accomplished three levels of project goals from 9 sites along the Middle Rio Grande, New Mexico Mean rank represents the average rank for that particular treatment compared to all other treatments and control with each region. Lowest ranks indicate the best treatment for accomplishing that goal.

\begin{tabular}{llcc}
\hline Variable Treatment & N & Mean Rank & Mean (SD) \\
\hline Total plant species richness & & & \\
\hline Treatment 1 (thinned) & 14 & 2.0 & $18.6(11.8)$ \\
Treatment 3 (re-veg) & 11 & 2.3 & $21.4(15.1)$ \\
Control & 13 & 1.7 & $24.9(8.1)$ \\
\hline Proportion of native plants & & & \\
\hline Treatment 1 (thinned) & 14 & 1.3 & $0.85(0.05)$ \\
Treatment 3 (re-veg) & 11 & 1.7 & $0.90(0.10)$ \\
Control & 13 & 3.0 & $0.76(0.04)$ \\
\hline Groundwater salvage (\%) & & & \\
\hline Treatment 1 (thinned) & 14 & 2.3 & $12.3(53.7)$ \\
Treatment 3 (re-veg) & 11 & 1.0 & $95.2(123.6)$ \\
$\quad$ Control & 13 & 2.7 & $0(0)$ \\
\hline Foliage diversity (H index) & & & \\
\hline Treatment 1 (thinned) & 14 & 2.3 & $0.33(0.45)$ \\
Treatment 3 (re-veg) & 11 & 2.0 & $0.38(0.29)$ \\
$\quad$ Control & 13 & 1.7 & $0.67(0.06)$ \\
\hline
\end{tabular}

\section{Discussion}

Resource managers along the Middle Rio Grande (MRG) in New Mexico could potentially select three different methodologies to achieve three levels of project goals (restoring biodiversity, ecosystem function, and communities). The decision whether to treat a riparian site impacted by exotic species, and if so how to treat the site, is an important one. The decision is important in terms of financial resources, as well as, ecological ramifications. Although, none of the treatments constitute restoration in terms of re-establishing ecosystem functions (i.e., natural flood regime or native plant recruitment) or a truly native-only condition, different treatments (or lack of treatment) can serve to emphasize potentially desirable natural characteristics of the MRG riparian ecosystem. Treatments may also cause secondary effects that managers must take into consideration in making effective decisions on treatments.

Therefore, to make wise management decisions, specific targets must be set, appropriate methods selected to achieve those objectives, secondary consequences must be evaluated, and ecological outcomes monitored.

\subsection{Ranking Restoration Treatments along the $M R G$}

All three treatments we evaluated were similar in reducing exotic woody species or creating a higher proportion of native plant species. Therefore, resource managers opting for the most cost 
effective method would best choose Treatment 1 to meet the explicit goal of removing exotic trees (Case Study I) and bolstering the proportion of native plants (Case Study II).

Conversely, if fuels reduction were the management objective, Treatment 2 and Controls were better at keeping ground fuels suppressed. Treatments 1 and 3 increased ground fuels and so their application could be counterproductive to meeting this specific goal. In these cases, fuels increased because treatments redistributed woody debris from the understory to the ground in the form of wood chips (i.e., small pieces of cut wood; [34]). Amount of fuels remaining after Treatment 2 were similar to other forest types where prescribed burns were used to reduce fuels and the risk of fire [34]. Controls contained greater amounts of dead and down trees in the understory compared to treatments [34]. This fallen and dead wood in the understory creates fuels that can increase the risk of fire in the riparian forest $[35,36]$.

Groundwater salvage is often an important goal of restoration because groundwater supports native riparian vegetation [37,38] and unsustainable groundwater development can threaten natural resources like riparian areas [39], groundwater can be a major source of user conflict and therefore is of management concern among natural resource managers. Case Study II, suggests that ground water salvage was greatest in restored sites with native plant revegetation, so removal of exotics through a number of means may best be used to meet this objective, while accepting the potential secondary consequences for vertical structure or herpetofauna richness. Therefore, adaptive management should include a temporal component. For example, vertical structure through restoration may be low initially and improve through time as plantings mature.

No treatment was ranked as the most effective means of meeting several restoration goals. In Case Study I, controls and all treatments experienced net gains of herpetofaunal species throughout the study period. This is similar to results of analyses on the effects of treatments on relative abundances of species of lizards. For example, Southwestern fence lizards (Sceloporus cowlesi, formerly S. undulatus complex) and Chihuahuan spotted whiptails (Aspidoscelis exanguis) responded positively to treatments and were associated with open understory habitats of restored sites [21], whereas amphibian species (i.e., Woodhouse's toad (Bufo woodhousii)) did not respond to treatments and instead responded to hydrological variables in the years following restoration (i.e., spring flooding in 2005 and summer rainfall in 2006; [40]. In Case Study II, structurally and compositionally heterogeneous stands of vegetation support diverse species assemblages [41,42]. Vertical substrate provides a wider variety of habitat niches, increasing potential bird species diversity [43,44]. There was no treatment which consistently provided the best habitat structure in our study because treatments ranked similar to or worse that the Control based on several possible project goals. Because of the importance often given to exotic plant control, managers would likely benefit from conducting restoration treatments; however, it may be important to leave large logs in place to add habitat structure to treated sites.

\subsection{Restoration Assessment Approaches}

In order to assess restoration success, managers and practitioners should clearly articulate the criteria which are being used to define restoration in light of management objectives and monitor project outcomes $[45,46]$. Monitoring can increase the understanding of possible trade-offs among 
restoration activities, allowing resource managers to implement ecologically sound restoration activities. Unfortunately, monitoring is an often overlooked and underfunded step in restoration projects. A comprehensive assessment of restoration projects in the USA found that only $10 \%$ of projects included monitoring [9]. Projects with inadequate or no monitoring limit the ability of managers to evaluate project success and failure, let alone implement adaptive approaches to redirect activities with negative or collateral effects on ecosystems [9]. Clearly defining goals with an understanding of possible trade-offs can aid natural resource managers to implement ecologically sound restoration activities.

Palmer et al. [47] suggest several criteria to evaluate the success of a restoration project. For example, restoration activities should not further damage already degraded ecosystems and project sites should be monitored before and after restoration implementation to provide evidence of improved condition. Other measures of success include whether a restored system reaches a level of self-sustainability and resilience [48]. At a minimum, managers should rank candidate sites based where restoration is most likely to be successful such as areas with resilience and low degradation [49]. The benefit of explicitly defining both project goals and ecological objectives should help to identify successes and failures $[8,9]$ among restorative projects.

We suggest that restoration projects include a monitoring plan and flexibility to modify activities which do not increase the ecological integrity of an ecosystem. If managers and practitioners pay particular attention to sustainable pathways before problems emerge, then solutions can be more cost-effective than attempting to remediate problems later [50]. First, projects should establish monitoring in sites at least one to two years prior to restoration activities. Monitoring should continue two to five years after implementation to detect short-term responses to restoration. Monitoring should target ecological variables relevant to documentation of desired system changes as well as potential secondary effects, such as negative impacts on vegetation structure or faunal composition. Because ecosystems are complex, restoration requires an approach that is based upon scientific evidence, flexibility, and the ability to respond to new information [51]. Therefore, managers need to document improvements and should allow for redirection of activities which further degrade ecosystem functions, such as habitat structure and native plant and wildlife recruitment in riparian forest restoration.

As seen from our analyses, varying stated project goals can lead to selection of different restoration methodologies. The root of confusion in restoration projects is using project goals, which are contextspecific, in the absence of overarching ecological objectives. Through experimentally testing the hypothesis, restoration treatments rank differently based upon varying project goals using two case studies, we demonstrated the necessity to include ecological objectives in restoration projects and the importance of monitoring project outcomes. Goals need to be refined and specific at project onset; otherwise, resource managers and practitioners risk conducting restoration activities with little or no guidance for correction or adaptation.

\section{Acknowledgments}

We thank Howard Snell for discussions and comments on earlier versions of this manuscript. We thank Tom Giermakowski Collection Manager from the Division of Amphibians and Reptiles at the 
Museum of Southwestern Biology for records of georeferenced specimens. We thank Rudy King USDA Forest Service, Rocky Mountain Research Station Statistical Unit for development of macros for the multi-response permutation procedure. We thank Mary Harner for permission to use photo in Figure 1(a). We thank the U.S. Bureau of Reclamation for financial assistance.

\section{Conflict of Interest}

The authors declare no conflict of interest.

\section{References}

1. SER (Society for Ecological Restoration International) Science \& Policy Working Group. The SER International Primer on Ecological Restoration, Society for Ecological Restoration International: Tucson, AZ, USA, 2004. Available online: http://www.ser.org (accessed on 1 February 2012).

2. Van Diggelen, R.; Grootjans, A.P.; Harris, J.A. Ecological restoration: State of the art or state of the science? Restor. Ecol. 2001, 9, 115-118.

3. Ruiz-Jaén, M.C.; Aid, T.M. Restoration success: How is it being measured? Restor. Ecol. 2005, 13, 569-577.

4. McCoy, E.D.; Mushinsky, H.R. Measuring the success of wildlife community restoration. Ecol. Appl. 2002, 12, 1861-1871.

5. Nichols, O.G.; Nichols, F.M. Long-term trends in faunal recolonization after bauxite mining in the jarrah forest of southwestern Australia. Restor. Ecol. 2003, 11, 261-272.

6. Rhoades, C.C.; Eckert, G.E.; Coleman, D.C. Effect of pastures trees on soil nitrogen and organic matter: Implications for tropical montane forest restoration. Restor. Ecol. 1998, 6, 262-270.

7. Hobbs, R.J.; Norton, D.A. Towards a conceptual framework for restoration ecology. Restor. Ecol. 1996, 4, 93-110.

8. Hobbs, R.J.; Harris, J.A. Restoration ecology: Repairing the Earth's ecosystems in the new millennium. Restor. Ecol. 2001, 9, 239-246.

9. Bernhardt, E.S.; Palmer, M.A.; Allan, J.D.; Alexander, G.; Barnas, K.; Brooks, S.; Carr, J.; Clayton, S.; Dahm, C.; Follstad-Shah, J.; et al. Ecology-Synthesizing U.S. river restoration efforts. Science 2005, 308, 636-637.

10. Matthews, J.W.; Endress, A.G. Performance criteria, compliance success, and vegetation development in compensatory mitigation wetlands. Environ. Manag. 2008, 41, 130-141.

11. Molles, M.C., Jr.; Crawford, C.S.; Ellis, L.M.; Valett, H.M.; Dahm, C.N. Managed flooding for riparian ecosystem restoration: Managed flooding reorganizes riparian forest ecosystems along the middle Rio Grande in New Mexico. BioScience 1998, 48, 749-756.

12. Roelle, J.E.; Hagenbuck, W.W. Surface Cover Changes in the Rio Grande Floodplain 1935-1989. In Our Living Resources: A Report to the Nation on the Distribution, Abundance, and Health of U.S. Plants, Animals, and Ecosystems; LaRoe, E.T., Farris, G.S., Puckett, C.E., Doran, P.D., Mac, M.J., Eds.; U.S. Department of the Interior, National Biological Service: Washington, DC, USA, 1995; pp. 290-292. 
13. Howe, W.H.; Knopf, F.L. On the imminent decline of Rio Grande cottonwoods in Central New Mexico. Southwest. Nat. 1991, 36, 218-224.

14. Taylor, J.P.; Wester, D.B.; Smith, L.M. Soil disturbance, flood management, and riparian woody plant establishment in the Rio Grande floodplain. Wetlands 1999, 19, 372-382.

15. Ellis, L.M.; Molles, M.C., Jr.; Crawford, C.S. Influence of experimental flooding on litter dynamics in a Rio Grande riparian forest, New Mexico. Restor. Ecol. 1999, 7, 193-204.

16. Medica, P.A. Food habits, habitat preferences, reproduction, and diurnal activity in four sympatric species of whiptail lizards (Cnemidophorus) in South Central New Mexico. Bull. South. Calif. Acad. Sci. 1967, 66, 251-276.

17. Burton, T.M.; Likens, G.E. Energy flow and nutrient cycling in salamander populations in the Hubbard Brook Experimental Forest, New Hampshire. Ecology 1975, 56, 1068-1080.

18. Van der Schalie, W.H.; Gardner, H.S., Jr.; Bantle, J.A.; de Rosa, C.T.; Finch, R.A.; Reif, J.S.; Reuter, R.H.; Backer, L.C.; Burger, J.; Folmar, L.C.; et al. Animals as sentinels of human health hazards of environmental chemicals. Environ. Health Perspect. 1999, 107, 309-315.

19. Collins, J.P.; Storfer, A. Global amphibian declines: Sorting the hypotheses. Divers. Distrib. 2003, 9, 89-98.

20. Canterbury, G.E.; Martin, T.E.; Petit, D.R.; Petit, L.J.; Bradford, D.F. Bird communities and habitat as ecological indicators of forest condition in regional monitoring. Conserv. Biol. 2000, 14, 544-558.

21. Bateman, H.L.; Chung-MacCoubrey, A.; Snell, H.L. Impact of non-native plant removal on lizards in riparian habitats in the southwestern United States. Restor. Ecol. 2008, 16, 180-190.

22. Hink, V.C.; Ohmart, R.D. Middle Rio GRANDE Biological Survey. In Final Report to the U.S. Army Corps of Engineers Contract No. DACW47-81-C-0015, Center for Environmental Studies; Arizona State University: Tempe, AZ, USA, 1984.

23. Stuart, J.N.; Farley, G.H.; Valdez, E.W.; Bogan, M.A. Studies of Vertebrates in Selected Riparian and Aquatic Habitats on Bosque del Apache National Wildlife Refuge, New Mexico; U.S. Fish and Wildlife Service: Albuquerque, NM, USA, 1995.

24. Degenhardt, W.G.; Painter, C.W.; Price, A.H. Amphibians and Reptiles of New Mexico; University of New Mexico Press: Albuquerque, NM, USA, 1996.

25. Fire Program Solutions/Acacia Services. Fuels Management Analyst, DD WoodyPC, Dead and Down Woody Material, Version 1.2.41. Available online: http://www.fireps.com (accessed on 1 October 2009).

26. Colwell, R.K.; Coddington, J.A. Estimating terrestrial biodiversity through extrapolation. Philos. Trans. R. Soc. Lond. B. Biol. Sci. 1994, 345, 101-118.

27. Colwell, R.K. EstimateS: Statistical Estimation of Species Richness and Shared Species from Samples. Version 8.2. User's Guide and Application; University of Connecticut: Storrs, CT, USA, 2009. 
28. Merritt, D.M.; Johnson, B.J. Response of Vegetation to Mechanical Removal of Exotic Plants, RMRS Middle Rio Grand Fuels Reduction Study (FRS): Progress to Date. In Effects of Fuel Reduction and Exotic Plant Removal on Vertebrates, Vegetation and Water Resources in the Middle Rio Grande, New Mexico, Final Report to the Joint Fire Sciences Program; Finch, D.M., Chung-MacCoubrey, A., Jemison, R., Merritt, D., Johnson, B., Campana, M., Eds.; USDA Forest Service Rocky Mountain Research Station: Albuquerque, NM, USA, 2006; pp. 56-69.

29. Gunning, C. Estimating phreatophyte evapotranspiration from diel groundwater fluctuations in the Middle Rio Grande bosque. M.S. Thesis, University of New Mexico, Albuquerque, NM, USA, 2010.

30. Petrondas, D.A.; Gabriel, K.R. Multiple comparisons by rerandomization tests. J. Am. Statist. Assoc. 1983, 78, 949-957.

31. Zar, J.H. Biostatistical Analysis, 3rd ed.; Prentice Hall: Upper Saddle River, NJ, USA, 1996.

32. U.S. Department of Agriculture (USDA) Forest Service, Southwestern Region. Strategy for Long-Term Management of Exotic Trees in Riparian Areas New Mexico's Five River Systems, 2005-2014; U.S. Department of Agriculture Forest Service: Washington, DC, USA, 2004.

33. Najmi, Y. Planner. Middle Rio Grande Conservancy District. Personal communication, 2007.

34. Merritt, D.M.; Scott, M.L.; Johnson, B.J. Riparian Vegetation Response to Control of Invasive Plant Species: Restoration or Retrogression. In Proceedings of Tamarisk Research Conference: Current Status \& Future, Fort Collins, CO, USA, 3-4 October 2006.

35. Agee, J.K.; Skinner, C.N. Basic principles of forest fuel reduction treatments. For. Ecol. Manag. 2005, 211, 83-96.

36. Stuever, M.C. Fire induced mortality of Rio Grande cottonwood. M.S. Thesis, University of New Mexico, Albuquerque, NM, USA, 1997.

37. Stromberg, J.C. Restoration of riparian vegetation in the south-western United States: Importance of flow regimes and fluvial dynamism. J. Arid Environ. 2001, 49, 17-34.

38. Baird, K.J.; Stromberg, J.C.; Maddock, T. Linking riparian dynamics and groundwater: An ecohydrologic approach to modeling groundwater and riparian vegetation. Environ. Manag. 2005, 36, 551-564.

39. Cooper, D.J.; D’Amico, D.R.; Scott, M.L. Physiological and morphological response patterns of Populus deltoides to alluvial groundwater pumping. Environ. Manag. 2003, 31, 215-226.

40. Bateman, H.L.; Harner, M.J.; Chung-MacCoubrey, A. Abundance and reproduction of toads (Bufo) along a regulated river in the southwestern United States: Importance of flooding in riparian ecosystems. J. Arid Environ. 2008, 72, 1613-1619.

41. Woinarski, J.C.Z.; Recher, H.F.; Majer, J.D. Vertebrates of Eucalypt Formations. In Eucalypt Ecology: Individuals to Ecosystems; Williams, J.E., Woinarski, J.C.Z., Eds.; Cambridge University Press: Cambridge, UK, 1997; pp. 303-341.

42. McElhinny, C.; Gibbons, P.; Brack, C.; Bauhus, J. Forest and woodland stand structural complexity: Its definition and measurement. For. Ecol. Manag. 2005, 218, 1-24.

43. MacArthur, R.H.; MacArthur, J.W. On bird species-diversity. Ecology 1961, 42, 594-605.

44. Merritt, D.M.; Bateman, H.L. Linking streamflow and groundwater to avian habitat in a desert riparian system. Ecol. Appl., in press. 
45. Bernhardt, E.S.; Sudduth, E.B.; Palmer, M.A.; Allan, J.D.; Meyer, J.L.; Alexander, G.; Follastad-Shah, J.; Hassett, B.; Jenkinson, R.; Lave, R.; et al. Restoring rivers one reach at a time: Results from a survey of U.S. river restoration practitioners. Restor. Ecol. 2007, 15, 482-493.

46. Holl, K.D.; Cairns, J., Jr. Monitoring and Appraisal. In Handbook of Ecological Restoration Vol. 1, Principles of Restoration; Perrow, M.R., Davy, A.J., Eds.; Cambridge University Press: Cambridge, UK, 2002; pp. 411-432.

47. Palmer, M.A.; Bernhardt, E.S.; Allan, J.D.; Lake, P.S.; Alexander, G.; Brooks, S.; Carr, J.; Clayton, S.; Dahm, C.N.; Shah, J.F.; et al. Standards for ecologically successful river restoration. J. Appl. Ecol. 2005, 42, 208-217.

48. Giller, P.S. River restoration: Seeking ecological standards. Editor's introduction. J. Appl. Ecol. 2005, 42, 201-207.

49. Holl, K.D.; Aide, T.M. When and where to actively restore ecosystems? For. Ecol. Manag. 2011, 261, 1558-1563.

50. Chapin, F.S.; Power, M.E.; Pickett, S.T.A.; Freitag, A.; Reynolds, J.A.; Jackson, R.B.; Lodge, D.M.; Duke, C.; Collins, S.L.; Power, A.G.; et al. Earth Stewardship: Science for action to sustain the human-earth system. Ecosphere 2011, 2, 1-20.

51. DellaSala, D.A.; Martin, A.; Spivak, R.; Schulke, T.; Bird, B.; Criley, M.; van Daalen, C.; Kreilick, J.; Brown, R.; Aplet, G. A citizen's call for ecological forest restoration: Forest restoration principles and criteria. Ecol. Restor. 2003, 21, 14-23.

(C) 2012 by the authors; licensee MDPI, Basel, Switzerland. This article is an open access article distributed under the terms and conditions of the Creative Commons Attribution license (http://creativecommons.org/licenses/by/3.0/). 